\title{
Immunity, infectious diseases and the knowledge of 100 Latvian pregnant women of the impact of infectious diseases on the pregnancy and its prevention
}

\author{
Anna Abramova* \\ Department of Medicine, Rigas Stradins University, Riga, Latvia \\ Received: 05 May 2015 \\ Revised: 18 May 2015 \\ Accepted: 06 June 2015 \\ *Correspondence: \\ Dr. Anna Abramova, \\ E-mail: abramova.anna.4@gmail.com \\ Copyright: (C) the author(s), publisher and licensee Medip Academy. This is an open-access article distributed under \\ the terms of the Creative Commons Attribution Non-Commercial License, which permits unrestricted non-commercial \\ use, distribution, and reproduction in any medium, provided the original work is properly cited.
}

\begin{abstract}
Infection diseases may adversely affect the pregnancy, lead to the development of foetal abnormalities, foetal death, congenital infections and preterm birth. Infection is possible in antenatal, postnatal and intranatal way. CMV, adenovirus, enterovirus are the most common viruses which are found during the examination of amniotic fluid. Hundred Latvian pregnant women were offered to fill in the questionnaire with the help of which it will be possible to study their knowledge on infectious diseases during pregnancy and preventive options. The obtained data were compared with foreign literature and foreign studies. Respondents' age was from 19 to 43 years. Only 65\% of women are aware that the risk of contracting infectious diseases during pregnancy is higher. Only $7 \%$ of women know about all possible ways of infection during pregnancy. $68 \%$ of women note that bacterial vaginosis may harm foetus and adversely affect pregnancy. Compared to the study conducted in Japan, Latvian pregnant women know about toxoplasmosis $4 \%$ more often than in Japan. Knowledge of pregnant women about the impact of infectious diseases on the foetus and pregnancy, potential infection and prevention ways is insufficient. Women want to know and receive understandable information from health care professionals.
\end{abstract}

Keywords: Pregnancy, Infection diseases, Pregnant women, Complication, Prevention, Riga

\section{INTRODUCTION}

Infection diseases may adversely affect the pregnancy, lead to the development of foetal abnormalities, foetal death, congenital infections and preterm birth. During pregnancy relations between first-class and second-class $\mathrm{T}$ helper cells change, cellular immunity weakens and it increases the risk of infectious diseases caused by intracellular microorganisms. Foetus and new-born can get infected in uterus and also in intranatal or postnatal period. At birth the impact of infectious diseases might not be immediately visible, but progress during lifetime. For those mothers who are infected with Toxoplasma gondii during pregnancy new-borns at birth may have no symptoms, but later in life visual and hearing impairment progresses, mental retardation is also observed.

\section{The immune system in pregnancy}

Foetus for mother's organism is genetically unfamiliar; immune system begins to operate against it. Therefore in order to have successful pregnancy maternal cellular immunity weakening occurs, it becomes tolerant to the foetus. ${ }^{1}$ The changes are observed at local, deciduous layer of the immune system and the whole body protection is becoming weaker. After implantation trophoblast of the foetus grows into the endometrium, which in turn becomes the deciduous layer that is to ensure full functioning and attachment of the placenta. At this stage, immune response balance is important, so it would not be too weak or too strong, since it affects the uterine wall preparation for the unborn child. If the response is too strong, trophoblast cells will not be able 
to grow into endometrium and the foetus will be repelled, but if the response is clearly weak, then trophoblast cells can grow through the uterine wall. Balance is ensured by adequate activity of uterine wall natural killer (NK) cells and macrophage. In this layer are also $\mathrm{T}$ helper cells, $\mathrm{T}$ cytotoxic lymphocytes. Dendritic cells are involved in the creation of immune tolerance. Number and type of immune cell in deciduous layer varies depending on the time of pregnancy. Number of NK cells and macrophages decreases in the second trimester. Immune cells also produce cytokines and angiogenesis factors that are important in the process of implantation of blastocyst and placentation. It interleukin 1 induces remodelling of spiral arteries. ${ }^{1,2}$

After the establishment of blood vessels in the placenta, maternal peripheral blood comes into contact with the foetus; at this stage response of maternal peripheral immune system is important. During pregnancy the number of monocytes and granulocytes increases, decreases the number of peripheral NK cells and interferon gamma produced by them, as well as the relation of killer cells $1 /$ and killer cells 2 . During pregnancy cellular immunity relatively lowers, reaching the lowest scores in the third trimester. Humoral immune response during pregnancy does not change., ${ }^{2,3}$

Humoral or antibody-mediated immunity is more sensitive to the extracellular microorganisms than cellular immunity. Macrophages on their surface present to B lymphocytes microorganism antigen, but second class $\mathrm{T}$ helper cells (Th2) stimulate proliferation of B lymphocytes. B lymphocytes synthesize specific antibodies that surround the micro-organism, which is further ingested by macrophages and neutrophil leukocytes. ${ }^{3}$

Cell immune response is directed to recognize and destruct infected body cells of intracellular microorganism. In this process first-class $\mathrm{T}$ helper cells (Th1) have important role. Th1 recognizes infected cells in the body, synthesizes interleukin 2, it activates $T$ cytotoxic lymphocytes, which produce cytotoxins that cause death of infected cells. ${ }^{3}$

During pregnancy Th2 was more active than Th1. Changes in the Th2/Th1 relations during pregnancy have not been fully understood. Following theories are expressed:

1. Hormonal changes during pregnancy;

2. Macrophages in uterine wall secrete Th2 stimulating cytokines that in reverse reduce Th1 proliferation;

3. Th2 activates B lymphocytes that synthesize antibodies. The presence of antibodies reduces proliferation of Th1. ${ }^{3}$

Th2 predominance over Th1 during pregnancy protects the foetus from the mother's cell-mediated immunity, yet increases the risk of infectious diseases caused by intracellular viruses, bacteria and parasites. ${ }^{4}$
As the mother's organism is less protected from the risk of infectious diseases, it is more likely to get infected for both, mother and the foetus. ${ }^{5}$

Primary infection during pregnancy is more dangerous because in the mother's body have not yet been developed IgG antibodies against certain microorganisms. IgG antibodies are able to cross the placenta and provide passive immunity to the new-born. ${ }^{6}$

Infection is possible in antenatal, postnatal and intranatal way. (Table 1)

Table 1: Ways in which some infectious agents spread.

\begin{tabular}{|c|c|c|}
\hline \multirow[t]{3}{*}{$\begin{array}{l}\text { Antenatal } \\
\text { infection }\end{array}$} & $\begin{array}{l}\text { Ascending } \\
\text { infection }\end{array}$ & $\begin{array}{l}\text { Group B } \\
\text { streptococcal } \\
\text { infection } \\
\text { Group A } \\
\text { streptococcal } \\
\text { infection } \\
\text { Escherichia coli } \\
\text { Chlamydia } \\
\text { infection }\end{array}$ \\
\hline & $\begin{array}{l}\text { Hematogenous } \\
\text { spread }\end{array}$ & $\begin{array}{l}\text { TORCH } \\
\text { infections } \\
\text { Listeriosis }\end{array}$ \\
\hline & $\begin{array}{l}\text { Iatrogenic } \\
\text { infection }\end{array}$ & $\begin{array}{l}\text { HIV infection } \\
\text { Hepatitis B } \\
\text { infection } \\
\text { Hepatitis C } \\
\text { infection }\end{array}$ \\
\hline $\begin{array}{l}\text { Intranatal } \\
\text { infection }\end{array}$ & $\begin{array}{l}\text { Contamination } \\
\text { while passing } \\
\text { through the } \\
\text { vagina }\end{array}$ & $\begin{array}{l}\text { Group B } \\
\text { streptococcal } \\
\text { infection } \\
\text { Chlamydia } \\
\text { infection } \\
\text { Gonococcal } \\
\text { infection } \\
\text { HIV infection } \\
\text { Herpes virus }\end{array}$ \\
\hline $\begin{array}{l}\text { Postnalat } \\
\text { infection }\end{array}$ & $\begin{array}{l}\text { During } \\
\text { breastfeeding }\end{array}$ & $\begin{array}{l}\text { HIV infection } \\
\text { Cytomegalovirus }\end{array}$ \\
\hline
\end{tabular}

Normally amniotic cavity environment is sterile. Infectious diseases may take place in sub-clinical way, so in case of suspicion amniocentesis can be carried out to approve microbial infestation, but basically for approval of asymptomatic infection after the birth the sample of placenta is taken and sent for microscopic examination. Not always infectious agents can be found during examination of amniotic fluid because of the microorganisms that infect the deciduous layer, as well as the gap between the choroidal and amniotic shells, and amniotic liquid remains sterile. For pregnant women with preterm deliveries and unruptured membranes positive amniotic fluid culture is $22 \%$. If there has been a premature bursting of shell and premature birth, then a positive culture is $32.4 \%$. For women with cervical abnormalities, such as short cervix found in ultrasound 
$(<25 \mathrm{~mm})$, microbial invasion in the amniotic cavity can happen in $9 \%$ of cases. $^{7}$

CMV, adenovirus, enterovirus are the most common viruses which are found during the examination of amniotic fluid. The virus genome is found in $15 \%$ of asymptomatic, low-risk pregnancies and $41 \%$ of pregnancies with viral infection risks. ${ }^{7}$

The knowledge of 100 Latvian pregnant women of the impact of infectious diseases on the pregnancy and its prevention.

Hundred Latvian pregnant women were offered to fill in the questionnaire with the help of which it will be possible to study their knowledge on infectious diseases during pregnancy and preventive options. Respondents' age was from 19 to 43 years. During data analysis, respondents were divided into two age groups: 27 women up to 25 years and 73 women over the age of 25 . People younger than 25 years are at risk of contracting sexually transmitted diseases and in the study of this part of population participated 27 women. ${ }^{8}$ In 2011, Latvian women became sexually active at the age of 17.46 on average. ${ }^{9}$ It is important that in this age people are aware of sexually transmitted diseases, causes of infection and prevention opportunities, because chronic infections may cause complications. Some complications include ectopic pregnancy, cervicitis, Bartolin's glandular inflammation and the development of oviduct adhesions that cause infertility.

Place of residence for $85 \%$ of pregnant women is Riga or Riga district and 52\% of women have higher education. 44 women have first pregnancy.

Only $65 \%$ of women are aware that the risk of contracting infectious diseases during pregnancy is higher, while $17 \%$ think the opposite that during pregnancy the defence activity of immune system becomes higher and women have lower risk of infection, the rest believe that the immune response does not change. In the age group of $\leq 25$ years of higher risk of infection during pregnancy are aware 19 women $(70 \%)$, but in the age group over 25 years of this risk are aware 46 women $(63 \%) \cdot(\mathrm{p}=0,493)$

Only $7 \%$ of women know about all possible ways of infection during pregnancy. More detailed knowledge is about the possible contamination during childbirth (Figure 1).

During pregnancy $38 \%$ of women complained about burning, itching and enhanced genital fluids. $68 \%$ of women note that bacterial vaginosis may harm foetus and adversely affect pregnancy. There are no statistically significant differences in knowledge between the different age groups and women with different educational levels. Since bacterial vaginosis may adversely affect the pregnancy and is the most common cause of genital secretions for women in childbearing age, it is important that the awareness of this disease risk would be even greater in all age groups. ${ }^{10}$ Results of a study performed in Latvia show that in 2003, $13 \%$ of men suffering from sexually transmitted diseases and $11 \%$ of women did not inform their sexual partners about it. ${ }^{9}$ Women should be encouraged to choose sexual partners responsibly and to inform partners about their health.

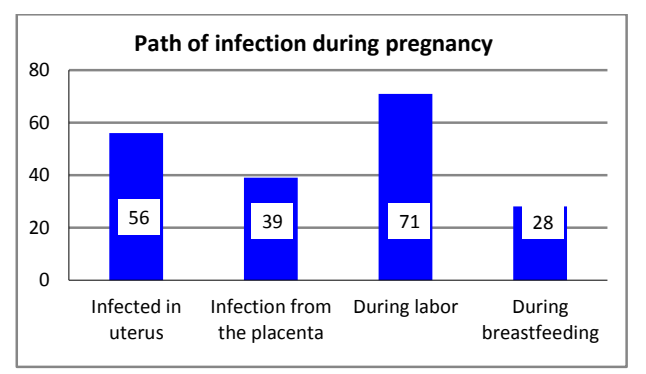

Figure 1: Maternity knowledge about possible routes of infection diseases during pregnancy.

About negative effects of TORCH infections during pregnancy knows more than $60 \%$ of surveyed women. About the dangers of toxoplasmosis are aware 61 pregnant women. Infection with toxoplasmosis can occur during contact with an faeces of infected cat, soil, during the consumption of uncooked meat. During pregnancy $52 \%$ of women have contact with a cat, $24 \%$ of women eat raw fish, $6 \%$ eat raw meat. $33 \%$ of women use hand hygiene as infection prevention during pregnancy. These results reflect the fact that knowledge about the risk of infection is greater than the knowledge about the possible preventive measures. Compared to the study conducted in Japan, Latvian pregnant women know about toxoplasmosis $4 \%$ more often than in Japan. ${ }^{11}$

Most CMV infections are asymptomatic, which increases the risk of infecting the foetus. If the health expert suspects CMV infection he has to designate specific laboratory examination that can confirm infection with CMV. High incidence of infection and vertical transmission may be the reason for inclusion of mandatory testing for CMV into the list of examinations performed during antenatal care. ${ }^{12}$ In the Japanese study $18 \%$ of respondents know about CMV infection, in France $-60 \%$, in Latvia $65 \%$ of pregnant women are aware of CMV. Latvian pregnant women are more aware of CMV infection than the Japanese and French research respondents. ${ }^{11,13}$

More than $80 \%$ of women believe that viral hepatitis B, C and HIV infection during pregnancy is dangerous. The surveyed women do not have a clear idea about HIV transmission ways. About a prohibition for HIV-positive mother to feed the new-born with breast milk are aware of $52 \%$ of women.

Only $74 \%$ of women admit that their oral cavity is healthy, while $11 \%$ of pregnant women within the last year have not visited the dentist. Study conducted in 
United States of America shows that $35 \%$ of pregnant women have not visited a dentist within the last year. ${ }^{14}$ Latvian respondents are visiting the dentist more frequently. One of the causes of oral infections may be GBS. Infectious diseases are one of the most common causes of neonatal mortality in the world. During pregnancy woman must have a healthy mouth cavity, as during pregnancy there is a higher risk of oral infection relapse and the development of a new infection. It is advisable while planning a pregnancy to visit a dentist and remediate damaged teeth. A woman can go to the dentist during pregnancy as well. In daily life it is recommended for woman to reject sweetened foods and drinks, brush teeth with fluoride toothpaste at least twice a day and visit dentist twice a year.

During pregnancy 30 women out of 100 had a history of infectious diseases. The most common types of diseases are referred to acute respiratory viral infection, 27 women note flu-like symptoms, and only one woman had a rash. 12 women out of 100 had a contact with a person who has expressed signs of infectious disease during pregnancy.

The results showed that $70 \%$ of pregnant women are aware of the fact that during pregnancy only certain vaccines and antibiotics are permitted; only $4 \%$ of women believe that during pregnancy all antibacterial remedies can be used. Such wide awareness may reduce the risk of using medicine that harms the foetus during pregnancy.

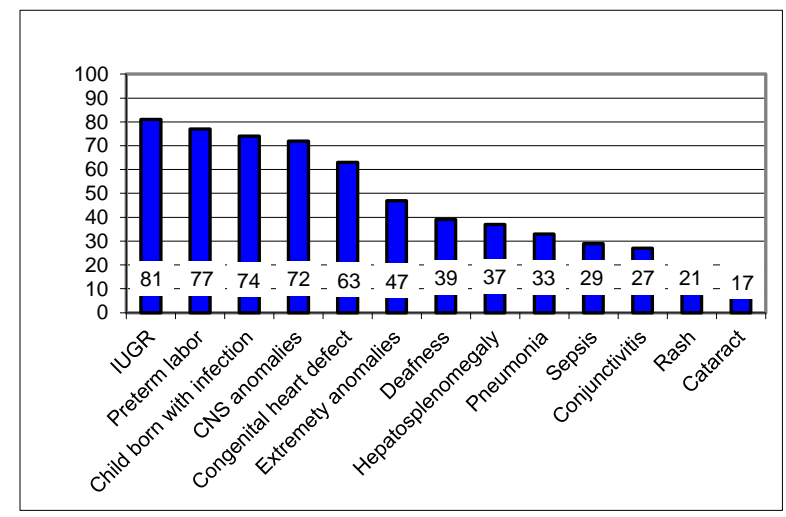

Figure 2: Infection diseases impact on the pregnancy and pregnancy outcome.

Pregnant women have the knowledge about the potential consequences of infectious diseases on the foetus (Figure 2). As the most common manifestation is marked intrauterine foetal growth restriction (IUGR). About possible development of IUGR in the age group of $\leq 25$ years know $81 \%$ of women, in the age group of $>25$ years know $81 \%$ of women. $(p=0.617)$ Of the respondents who have their first pregnancy about the possible development of IUGR know $75 \%$ of women, of the respondents with recurrent pregnancy - 86\% of women. ( $p=0.175)$ Of women with higher education about the possible development of IUGR know $77 \%$ of respondents, with no higher education $-85 \%$. $(p=0,279)$ Only $29 \%$ of women know about the possible development of neonatal sepsis due to infectious diseases.

According to the study women turn to the doctor, visit websites, read magazines and newspapers. 57\% of pregnant women admit that their care professional has not provided sufficient information during pregnancy. In US study about knowledge of pregnant women about oral health $59 \%$ noted that they had not received valuable information from a caregiver. ${ }^{14}$ In Latvia $2 \%$ less number of women note that the information has been inadequate. Respondents are more likely to obtain the information they are interested in from the Internet than from a caregiver. This information may be misleading, inaccurate. Therefore it is important to give full, scientifically proven information to pregnant women and to all women who are planning pregnancy about negative impact of infectious diseases on the course of pregnancy, the foetus and potential complications prevention options. Information must be understandable and readily available.

Women gave an insight on the preventive measures that they take during pregnancy. As the most popular preventive measure was stated fresh fruit, berry and vegetable consumption. The third part noted that regular hand washing with soap is important. Third place in preventive measures take vitamins for pregnant women and complex vitamins. There are also women who do not comply with additional preventive measures and do not change their habits (Figure 3).

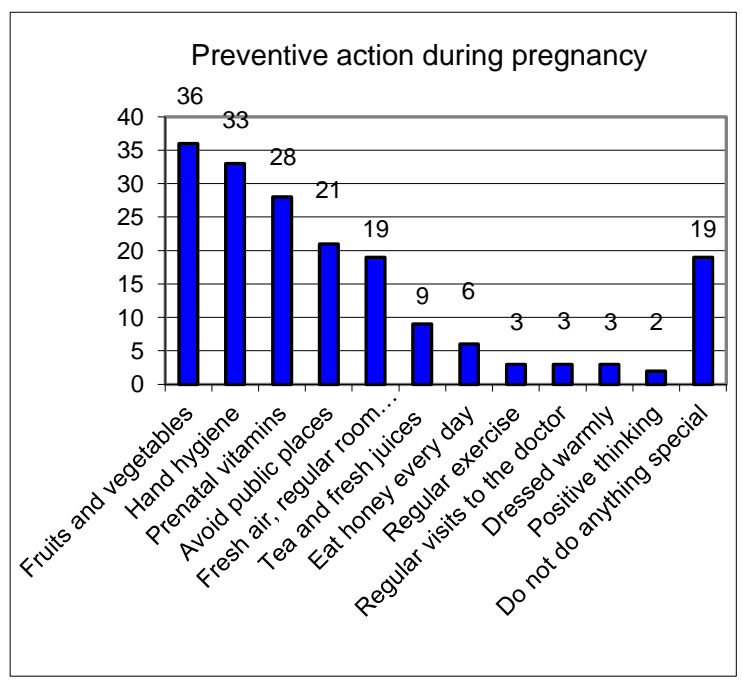

Figure 3: Preventive measures taken by the respondents during pregnancy in order to protect themselves from the infectious diseases.

Vaccination is the primary disease prevention. During pregnancy one woman received vaccine against influenza and encephalitis at the $29^{\text {th }}$ pregnancy week. 27 women received vaccine against influenza during lifetime, but during pregnancy decided not to receive the vaccine, because it is dangerous to the foetus, baby. $20 \%$ of the 
total number of pregnant women noted that they do not believe in influenza vaccine and do not consider it necessary. More knowledge about vaccination can protect mother and foetus from the development of possible complications. According to the List of Reimbursable Items state reimburses $50 \%$ of influenza vaccines for pregnant women. ${ }^{15}$ Centre for Disease Prevention and Control (CDPC) recommends everyone to get vaccinated against the influenza, noting in particular pregnant women and women who plan to become pregnant during the influenza season, because this group of people has a higher risk of infection. ${ }^{15}$ Foreign sources recognize vaccination against the influenza to be the best prevention measure. ${ }^{16}$

At the end of questionnaires pregnant women are given the opportunity to evaluate their knowledge, make recommendations and ask questions to health professionals. Almost half of women assess their knowledge as average. The most common recommendation to professionals is giving more extensive information to patients and showing greater interest in their health. Many made a proposal to create an information booklet.

\section{CONCLUSION}

- Th2 predominance over Th1 during pregnancy protects the foetus from the mother's cell-mediated immunity, yet increases the risk of infectious diseases caused by intracellular viruses, bacteria and parasites.

- Effects of infectious diseases on the pregnancy can be very different.

- Knowledge of pregnant women about the impact of infectious diseases on the foetus and pregnancy, potential infection and prevention ways is insufficient.

- Women want to know and receive understandable information from professionals.

Funding: No funding sources

Conflict of interest: None declared

Ethical approval: Not required

\section{REFERENCES}

1. Ingrid Koo, Ph.D. Infectious Diseases during Pregnancy - Risks to baby. Infections during pregnancy can be spread to unborn babies. 13 March 2009 Available at: http://infectiousdiseases. about.com/od/kidsinfections/a/Congenital.htm

Accessed 10 October 2014.

2. Herberts C, Melgert B, van der Laan JW, Faas M. Expert Rev Vaccines. New Adjuvanted Vaccines in Pregnancy: What is Known About Their Safety? September, 2010. 1411-1422. Available at: http://www.medscape.com/ viewarticle/734891_2 Accessed 13 October 2014.
3. Jamieson DJ, Theiler RN, Sonja A. Rasmussen. Emerging Infections and Pregnancy. Emergerncy Infection Diseases. 2006;12(11):1638-43.

4. Saito S, Nakashima A, Shima T, Ito M. Th1/Th2/Th17 and Regulatory T-Cell Paradigm in Pregnancy. American Journal of Reproductive Immunology. Mart. 2010;63:601-10.

5. Žodžika J, Vasina O, Lietuviete N. How Vaginal flora impact on pregnancy outcomes and adjustment options. Journal Doctus, Latvia. 2011;14-16.

6. Rezeberga D, Vītiņa Z, Jēruma A. Pregnancy and infection dieaseses", 1-2. Available at: http://www.ginasoc.lv/wp-content/uploads/ infekcijas.pdf. Accessed 10 November 2014.

7. Romero R, Espinoza J, Gonc,alves LF, Kusanovic JP, Friel L, Hassan S. The Role of Inflammation and Infection in Preterm Birth. Semin Reprod Med. 2007;25(1):21-39.

8. Chakraborty R, Luck S. Syphilis is on the increase: the implications for child health. Archives of Disease in childhood. 2007;93:105-9.

9. Cannon MJ. Congenital cytomegalovirus (CMV) epidemiology and awareness. Journal of Clinical Virology. 2009;46(4):6-10.

10. Caserta MT. Congenital Syphilis. New Jersey: Merck Manual, May, 2013 Available at: http://www.merckmanuals.com/professional/pediatri cs/infections_in_neonates/congenital_syphilis.html Accessed 1 December 2014

11. Oklahoma state department of health. Breastfeeding and the Flu. August, 2012. Available at: http://www. ok.gov/health2/documents/IMM_Flu_Breasfeeding.p df Accessed 1 December 2014.

12. Rockville: AIDS info. Recommendations for use of antiretroviral drugs in pregnant HIV-1-infected women for maternal health and interventions to reduce perinatal HIV. February, 2014. Available at: http://aidsinfo.nih.gov/guidelines. Accessed 3 December 2014.

13. National Health service. Can cytomegalovirus (CMV) harm my baby during pregnancy. April, 2013 Available at: http://www.nhs.uk/chq/Pages/1108. aspx?CategoryID $=54 \&$ SubCategoryID $=137$. Accessed 12 December 2014.

14. Barss VA. Patient information: Avoiding infections in pregnancy. Beyond the Basics. November, 2013. Available at : http://www.uptodate.com/ contents /avoiding-infections-in-pregnancy-beyond-thebasics. Accessed 12 December 2014.

15. The American Congress of Obstetrisians and Gynecologist. Oral Health Care During Pregnancy and Through the Lifespan. 2013. Available at: http://www.acog.org/Resources_And_Publications/C ommittee_Opinions/Committee_on_Health_Care_for _Underserved_Women/Oral_Health_Care_During_P regnancy_and_Through_the_Lifespan. Accessed 29 November $201 \overline{4}$.

16. Center for disease control and prevention. Parasites Toxoplasmosis (Toxoplasma infection) in pregnant women. January, 2013. Available at: http://www.cdc.gov/parasites/toxoplasmosis/gen_inf o/pregnant.html. Accessed 1 December 2014.

Cite this article as: Abramova A. Immunity, infectious diseases and the knowledge of 100 Latvian pregnant women of the impact of infectious diseases on the pregnancy and its prevention. Int J Reprod Contracept Obstet Gynecol 2015;4:954-8. 